\title{
LONCENG KEMATIAN PENDIDIKAN HUKUM DI INDONESIA TINJAUAN FILOSOFIS
}

\section{THE DEATH BELL OF LEGAL EDUCATION IN INDONESIA BASED ON PHILOSOPHICAL PERSPECTIVES}

\author{
Emi Puasa Handayani ${ }^{1}$, Zainal Arifin ${ }^{2}$ \\ ${ }^{1,2}$ Fakultas Hukum Universitas Islam Kadiri (Uniska), Kediri \\ Email: zainal.fh@uniska-kediri.ac.id \\ emipuasa.fh@uniska-kediri.ac.id/fakhukum100@gmail.com
}

\begin{abstract}
The paper entitled The Death alarm in Legal Education in Indonesia based on Philosophical perspective, raises two points, first, what is the nature of legal education? Secondly, what is the future formulation of legal education in Indonesia? Both problems will be answered using a philosophical, theoretical and juridical approach. The theory used to analyze the two problems is the abstraction theory of Aristotle and the psychoanalytic theory of Sigmund Freud. The first result is the essence of legal education is to mature students to be independent, objectively independent, have high character of noble character, intellectual, emotional, social and spiritual intelligence. Secondly, legal education in the future is designed to be able to create intelligent students in accordance with educational goals contained in the constitution, by emphasizing religious ethics, as well as incorporating integrated curriculum that emphasizes comprehensive and practical thinking.
\end{abstract}

Keywords: Death alarm, legal education

\section{Intisari}

Makalah berjudul Lonceng Kematian Pendidikan Hukum Di Indonesia Tinjauan Filosofis, mengangkat dua persolan yaitu pertama apa hakekat pendidikan hukum? Kedua bagaimana formulasi kedepan pendidikan hukum di Indonesia?. Kedua problem itu akan dijawab menggunakan pendekatan filosofis, teoritis dan yuridis. Teori yang digunakan untuk menganalisis kedua persoalan itu adalah teori abstraksi dari Aristoteles dan teori psikoanalisis dari Sigmund Freud. Hasilnya pertama hakekat pendidikan hukum adalah adalah mendewasakan anak didik untuk mandiri, obyektif independen, memilki karakter budi pekerti luhur, berkecerdasan intelektual, emosional, sosial dan spiritual yang tinggi. Kedua, pendidikan hukum kedepan dirancang untuk mampu menciptakan anak didik yang cerdas sesuai dengan tujuan pendidikan yang termuat dalam kosntitusi, dengan menekankan pada etika religius, serta memasukan kurikulum terintegrsi yang menekankan pada berfikir yang komprehensif praktis dan teoritis.

Kata Kunci: Lonceng kematian, pendidikan hukum 


\section{A. Latar Belakang}

Pendidikan tinggi hukum di Indonesia saat ini mengalami penurunan kualitas, salah seorang pakar pendidikan Prof Dr. Muhtar Buchori tahun 1985 pernah memperingatkan pada bangsa Indonesia terhadap matinya pendididkan di Indonesia. Muhtar menulis artikel dengan judul "Lonceng Kematian Pendidikan di Indonesia". Artikel itu ditulis dalam sebuah halaman opini di harian umum yang terbit di Jakarta. Kini setelah hampir 30 tahun lonceng kematian itu berbunyi mendering ditelinga kita bangsa Indonesia, pendidikan telah berubah arah dari spiritualisme menjadi materialisme. Pertanda jiwa ruh telah mati, dan lonceng berdering berkali kali. Apa hakaket dari pendidikan sebenarnya yang akan diraih bangsa Indonesia terutama dalam pendidikan hukum, apakah hanya sekedar tahu dan menjadi tukang hukum atau sebagai pemikir hukum saja, persolan inilah yang harus dirumuskan sejak awal mulai dari jenjang sarjana hingga doktor.

Bangsa Indonesia telah merumuskan tujuan pendidikan dalam konstitusi sebagai dasar terkuat dalam menjalankan pendidikan tinggi hukum. Tujuan pendidikan yang dicantumkan dalam dasar negara jarang ditemukan. Indonesia merupakan salah satu diantara negara di dunia yang mencantumkan tujuan pendidikan tersebu dalam konstitusi. Tujuan pendidikan di Indonesia tertuang dalam pembukaan Undang Undang Dasar Negara Republik Indonesia Tahun 1945, yaitu: Mencerdaskan kehidupan bangsa.

Tujuan Pendidikan Nasional dalam UUD 1945 (versi Amandemen), Pasal 31, ayat 3 menyebutkan, "Pemerintah mengusahakan dan menyelenggarakan satu sistem pendidikan nasional, yang meningkatkan keimanan dan ketakwaan serta akhlak mulia dalam rangka mencerdaskan kehidupan bangsa, yang diatur dengan undang-undang." Pasal 31, ayat 5 menyebutkan bahwa, "Pemerintah memajukan ilmu pengetahuan dan teknologi dengan menunjang tinggi nilai-nilai agama dan persatuan bangsa untuk kemajuan peradaban serta kesejahteraan umat manusia."

Sementara tujuan pendidikan menurut Undang-Undang Nomor 20 Tahun 2003 tentang Sistem Pendidikan Nasional (Sisdiknas), pasal 1 ayat (1) adalah: "Sebagai usaha sadar dan terencana untuk menciptakan suatu proses pembelajaran agar peserta didik secara aktif dapat mengembangkan potensi dirinya". Undangundang Nomor 20 Tahun 2003 Pasal 3, menegaskan adanya fungsi pendidikan yakni untuk mengembangkan kemampuan dan membentuk watak serta peradaban bangsa yang bermartabat dalam rangka mencerdaskan kehidupan bangsa. Tujuannnya agar peserta didik berkembang menjadi manusia yang beriman dan bertakwa kepada Tuhan yang maha Esa dan berakhlak mulia, berilmu, sehat, kreatif, cakap, mandiri dan demokratis serta bertanggungjawab.

Tujuan pendidikan tinggi juga tertuang dalam UU No. 12 Tahun 2012 tentang Pendidikan Tinggi yaitu pada pasal 5. Dalam UU No. 12 Tahun 2012 pasal 5 tersebut disebutkan 4 (empat) tujuan pendidikan tinggi, yaitu sebagai berikut: 1 . Berkembangnya potensi Mahasiswa agar menjadi manusia yang beriman dan bertakwa kepada Tuhan Yang Maha Esa dan berakhlak mulia, sehat, berilmu, cakap, kreatif, mandiri, terampil, kompeten, dan berbudaya untuk kepentingan bangsa. 2. Dihasilkannya lulusan yang menguasai cabang Ilmu Pengetahuan dan/atau Teknologi untuk memenuhi kepentingan nasional dan peningkatan daya saing bangsa.3. Dihasilkannya Ilmu Pengetahuan dan Teknologi melalui Penelitian 
yang memperhatikan dan menerapkan nilai Humaniora agar bermanfaat bagi kemajuan bangsa, serta kemajuan peradaban dan kesejahteraan umat manusia. 4 . Terwujudnya Pengabdian kepada Masyarakat berbasis penalaran dan karya Penelitian yang bermanfaat dalam memajukan kesejahteraan umum dan mencerdaskan kehidupan bangsa.

Akhir akhir ini bisa disaksikan pendidikan telah kehilangan arah, pendidikan telah tergerus, pendidikan tak lagi sebagai usaha sadar. Tidak lagi untuk mengembangkan potensi peserta didik secara utuh, agar bisa menghidupi dirinya sendiri, masyarakat dan lingkungannya. Tujuan pendidikan itu telah tergadaikan dan tercampak. Tak salah apabila kemudian ada yang menggugat terhadap jalannya pendidikan di Indonesia. Maklah ini salah satunya adalah ingin meluruskan apa yang seharusnya dilakukan perguruan tinggi untuk mencetak kader bangsa yang tetap menjunjung tinggi etika bernegara, menjadi sarjana yang mumpuni berkulitas dibidang hukum. Ada dua pertanyaan yang akan dijawab dalam makalah ini pertama, apa hakekat pendidikan hukum? Kedua bagaimana formulasi kedepan pendidikan hukum di Indonesia?. Kedua problem itu akan dijawab menggunakan pendekatan filosofis, teoritis dan yuridis. Harapannya dengan tiga pendekatan itu permasalahan dalam makalah ini akan terjawb dengan tuntas, komplit dan mendalam.

\section{B. Hakekat Pendidikan Hukum}

Sebelum membahas hakekat pendidikan hukum, penulis akan memaparkan tentang makna pendidikan. Pendidikan dalam bahasa Inggris education, artinya pembelajaran pengetahuan, keterampilan, dan kebiasaan sekelompok orang yang diturunkan dari satu generasi ke generasi berikutnya melalui pengajaran, pelatihan, atau penelitian.

Secara umum Pendidikan berarti usaha sadar dan terencana untuk mewujudkan suasana belajar dan proses pembelajaran untuk peserta didik agar secara aktif mengembangkan potensi dirinya untuk memiliki kekuatan spiritual keagamaan, pengendalian diri, kepribadian, kecerdasan, akhlak mulia, serta keterampilan yang diperlukan dirinya dan masyarakat.

Pakar lain mengatakan Pendidikan adalah usaha sadar dan sistematis untuk mencapai taraf hidup atau untuk kemajuan yang lebih baik, sehingga diharapkan pendidikan dapat mengembangkan karakter melalui berbagai macam kegiatan, misalkan penanaman nilai, berkembangnya budi pekerti, nilai agama, pembelajaran dan pelatihan nilai-nilal moral,serta lainnya Sederhananya pendidikanitu merupaka proses pembelajaran anak didik untuk dapat mengerti, paham, dan membuat anak didik kritis dalam berpikir. ${ }^{1}$

Secara etimologi atau asal kata Pendidikan berasal dari bahasa Latin E dan Duco atau educatum. Artinya E berarti sebuah perkembangan dari dalam ke luar atau dari sedikit menju banyak, sedangkan Duco berarti perkembangan atau sedang berkembang. Secara etimologi pengertian pendidikan adalah proses mengembangkan kemampuan diri sendiri dan kekuatan individu. ${ }^{2}$

\footnotetext{
${ }^{1}$ https://www.zonareferensi.com/pengertian-pendidikan/, diakses Senin 29 Juli 2019 pukul 10.30 ${ }^{2}$ Ibid
}

Suloh Jurnal Program Studi Magister Hukum, Vol. 8, No. 1, April 2020, pp. 3 - 11 
Adapun menurut Kamus Besar Bahasa Indonesia (KBBI) dicantumkan bahwa pendidkan dari kata 'didik' dan mendapat imbuhan 'pe' dan akhiran 'an', maka kata ini mempunyai arti proses atau cara atau perbuatan mendidik. "Secara bahasa definisi pendidikan adalah proses pengubahan sikap dan tata laku seseorang atau kelompok orang dalam usaha mendewasakan manusia melalui upaya pengajaran dan pelatihan". 3

Menurut John Dewey, pendidikan adalah usaha sadar yang dilakukan oleh orang dewasa kepada anak yang belum dewasa. Pendidikan merupakan suatu proses pengalaman. Karena kehidupan merupakan pertumbuhan, maka pendidikan berarti membantu pertumbuhan batin manusia tanpa dibatasi oleh usia. Proses pertumbuhan adalah proses penyesuaian pada setiap fase dan menambah kecakapan dalam perkembangan seseorang melalui pendidikan. ${ }^{4}$

Adapun kalau ditelusuri lebih mendalam terkait dengan definisi pendidikan maka akan terkait dengan tujuan pendidikan. Paling tidak ada dua rumusan tujuan pendididikan. Rumuasan itu terkait dengan usaha peningkatan kemampuan dan keilmuan, serta upaya untuk meningkatkan hubungan positif dengan hidup dan kehidupan manusia. ${ }^{5}$ Adapun rumusan tujuan pendidikan itu pertama adalah yang berorientasi pada kemasyarakatan yang cenderung mengutamakan peningkatan kualitas komunitas masyarakat dan yang kedua lenbih berorientasi pada individu yang lebih memfokuskan diri pada kebutuhan, daya tampung, dan minat pelajar. ${ }^{6}$

Konsolidasi kedua pandangan ini akan dapat mewujudkan suatu bentuk system pendidikan yang ideal karena mampu mensinergikan dua eleman sekaligus yaitu elemen individu dan kelompok. Oleh karena itu mengapa pemerintah di negara-negara maju sangat memperhatikan pendidikan yang terdapat upaya mensinergikan kedua elemen tersebut. Mereka beranggapan tentang adanya kekuatan besar dalam pendidikan untuk meningkatkan kemampuan individu dan juga masyarakat dalam rangka mencapai kehidupan yang lebih maju dan sejahtera. ${ }^{7}$

Pendidikan juga diartikan sebagai bentuk usaha manusia dewasa yang telah sadar akan kemanusiaannya dalam membimbing, melatih, mengajar dan menanamkan nilai-nilai serta dasar-dasar pandangan hidup kepada generasi muda untuk mengubah dan meningkatkan diri. ${ }^{8}$ Sementara M. Ngalim Purwanto mendefinisikan pendidikan sebagai usaha meningkatkan kemampuan individu khususnya anak yang berupa pimpinan yang diberikan dengan sengaja oleh orang

\footnotetext{
${ }^{3}$ Kamus Besar Bahasa Indonesia (KBBI)

${ }^{4}$ Op Cit, https://www.zonareferensi.com/pengertian-pendidikan/.

${ }^{5}$ Prasetya, Fisafat Pendidikan Untuk IAIN, PTAIN, PTAIS, Cetakan ke-dua, (Bandung: CV. Pustaka Setia, 2000), h. 13

${ }^{6}$ Hasan Langgulung, Pendidikan Islam Dalam Abad 21, Cetakan ketiga, (Jakarta; PT. Pustaka Al-Husna Baru, 2003), h. 69.

${ }^{7}$ Muhammad Attiyah Al-Abrasyii, Ruuhu At-Tarbiyah Wa At-Ta'liim, Cetakan Kesepuluh, (Al-Qoohirah; Daar Ihkyaau Al-Kutub Al-'Arobiyah, Tanpa Tahun), h. 8.

${ }^{8}$ Prasetya, op cit, hlm. 13.
} 
dewasa kepada anak dalam pertumbuhannya (jasmani dan rohani) agar berguna bagi diri sendiri dan bagi masyarakat. ${ }^{9}$

Menurut para pakar pendidikan, bahwa pendidikan itu mengandung berbagai pengertian. Pembahasan mengenai hakekat pendidikan hukum pernah di lakukan oleh beberapa pakar daataranya adalah Sigmud Freud, ia mengatakan bahwa arakter manusia terbentuk darai kepribadiannya yang di kenal dengan teori psikoanalisa yang mengatakan bahwa: Hakekat Manusia Terbentuk dari kepribadian, kepribadian adalah semua corak perilaku dan kebiasaan individu yang terhimpun dalam diri dan digunakan untuk bereaksi serta menyesuaikan diri terhadap segala rangsangan baik dari luar maupun dari dalam. Corak perilaku dan kebiasaan ini merupakan kesatuan fungsional yang khas pada seseorang Perkembangan kepribadian tersebut tersirat dinamis, artinya selama individu masih bertambah pengetahuannya dan mau belajar serta menambah pengalaman dan keterampilan, mereka akan semakin matang dan mantap kepribadiannya.

Berdasarkan beberapa penelitian pada klien yang mengalami masalah kejiwaan Freud menyimpulkan bahwa diri manusia dalam membentuk kepribadianya terdiri atas komponen utama yaitu das es, das ich, das uber Ich, istilah lainnya $i d$, ego, super ego. Untuk memudahkan pemahaman, id artinya nafsu atau dorongan-dorongan kenikmatan yang harus dipuaskan, bersifat alamiah pada manusia, ego dapat dianalogikan selagai kemampuan otak atau akal yang membimbing manusia untuk menarik jalan keluar terhadap masalah melalui penalarannya. Sedangkan super ego sebagai norma, aturan, agama, norma sosial. ${ }^{10}$

Sedangkan para ahli lainnya mengemukakan bahwa pengertian pendidikan " education is now engaged is preparinment for a tipe society which does not yet exist ", atau pendidikan sekarang ini sibuk mempersiapkan manusia bagi suatu tipe masyarakat yang belum ada. ${ }^{11}$ Menurut Garten. V. Good dalam dictionary of education mengemukakan bahwa pendidikan mengandung pengertian sebagai suatu proses perkembangan kecakapan seorang dalam bentuk sikap dan prilaku yang berlaku dalam masyarakat dan profesional dimana seorang dipengaruhi oleh suatu yang terpimpin ${ }^{12}$.

Terkait dengan teori psiko analisa yang dikemukakan Freud, jika di kaitkan dengan pendidikan maka, bisa dikatakan bahwa Pendidikan dalam hal psikoanalisis memiliki pengertian yang sangat luas, menunjuk kepada semua tindakan yang diterapkan oleh orang dewasa, ahli atau non-pakar, guru dan orang tua, untuk membentuk dan mempengaruhi perilaku anak (peserta didik) yang sedang tumbuh dengan cara yang diinginkan.

Pendidikan juga berarti tindakan perlindungan terhadap sikap peserta didik. Berdsarkan teori psikoanalisi ini menurut penulis maka seharusnya pendidikan tidak membiarkan anak didik untuk mengumbar nafsu, harus ada rem atau yang

${ }^{9}$ M. Ngalim Purwanto, Ilmu Pendidikan Teoritis Dan Praktis, Edisi Kedua, CetakanKelimabelas, (Bandung; PT. Remaja Rosdakarya, 2003), hlm. 11.

10 Rhara Irawan, Konseling Psikoanalisis, Sejarah Hidup Sigmund Freud, ttps://www.academia. edu/30268490

${ }^{11}$ M. Djumransjah, Pengantar Filsafat Pendidikan, Cetakan Pertama, (Malang; Bayu Media Publishing, 2004), h. 23.

${ }^{12}$ Ibid, hlm. 13

Suloh Jurnal Program Studi Magister Hukum, Vol. 8, No. 1, April 2020, pp. 5 - 11 
dapat mencegah nafsu bertindak dibawah kendali otak manusia, dan tentu harus dikendalikan dengan pengetahuan religi. Menurut Freud tujuan-tujuan pendidikan yang dinyatakan berdasarkan analisis psikoanalisis adalah memberi tuntunan bagi pendidik dan anak didik tentang apa yang hendak dicapai, kegiatan-kegiatan yang mereka lakukan, dan tentang kemajuan yang dicapai oleh anak didik. ${ }^{13}$

Pendidikan merupakan suatu usaha yang dilakukan oleh orang dewasa secara sadar yang telah memiliki dasar pengetahuan hidup yang lebih dari cukup untuk menanamkan nilai-nilai kehidupan serta pengetahuan tentang kehidupan kepada generasi muda dalam rangka memberikan dan meningkatkan kemampuan (inside competence dan outside competence) generasi muda dalam segala segi kehidupan baik secara jasmani maupun rohani dengan berbagai sarana agar generasi muda selanjutnya lebih berguna bagi dirinya sendiri, masyarakat, bangsa dan negaranya. ${ }^{14}$

Pendidikan jika dikaitkan dengan hukum, maka secara jelas menurut penulis, adalah mengandung maksud yang luas, sebab hukum sendiri maknanya juga sangat luas, bisa berarti aturan yang tertulis, bisa berarti undang-undang bisa berarti adat yang sudah berlangsung secara turun menurun meski tidak tertulis. Pertanyaan tentang apa itu hukum, sangat sulit untuk dijawab, mengungat aspek hukum itu sangat las dan bervariasi. Menurut penulis, definisi hukum tidak akan mampu mencakup keseluruhan makna hukum yang sesungguhnya, sebab definisi hukum pada dasarnya hanyalah kata-kata yang sempit dan terbatas. Pakar hukum Van Apeldoorn, sangat menyadari adanya keterbatasan manusia, yang tidak mungkin bisa memberikan definisi yang mampu mencakup semua makna yang dimaksud hukum sesuai dengan kenyataan yang sesungguhnya dari hukum tersebut. Lemaire dalam karyanya yang berjudul hukum di Indonesia juga tidak sanggup mendefinisikan karena seginya sangat banyak lapisannya sangat banyak. "Hukum yang banyak seginya serta meliputi segala lapisan itu menyebabkan tidak mungkin membuat definisi apa hukum itu sebenarnya.". ${ }^{15}$

Sulitnya mendefinisikan hukum itu juga di akui oleh Mr. Dr. Kisch, karena hukum itu tidak bisa dilihat dan ditangkap oleh panca indra, sehingga manusia sulit untuk mendefinisikan. Meski demikian penulis mencoba untuk mencari definisi hukum yang sesuai dengan judul makalah ini, diantaranya definisi yang dirumuskan dalam Kamus Besar Bahasa Indonesia (KBBI), hukum diartikan sebagai peraturan atau adat yang secara resmi dianggap mengikat yang dikukuhkan oleh penguasa atau pemerintah.

Untuk memperluas definisi hukum sebagai perbandingan maka penulis memilih beberapa pakar yaitu Plato, yang mengatakan bahwa hukum adalah: merupakan sebuah peraturan yang teratur dan tersusun dengan baik. Serta dapat mengikat terhadap masyarakat ataupun pemerintah. Pemikir lainnya yaitu Utrecht berpendapat bahwa hukum adalah himpunan petunjuk hidup berupa perintah dan larangan yang mengatur tata tertib masyarakat. Tata tertib tersebut harus dipatuhi masyarakat. Jika melanggar maka akan menimbulkan tindakan dari pemerintah.

\footnotetext{
${ }^{13}$ Halelaluddin Syawal, Psikoanalisis Sigmund Freud dan Implikasinya dalam Pendidikan, www.researchgate.net/publication/323535054

${ }^{14}$ Alif Cahya Setiyadi, Konsep Demokrasi Pendidikan Menurut John Dewey, At-Ta'dib Vol. 5. No. 1 Shafar 1430 , hlm. 80

${ }^{15}$ Sri Warjiyati, Memahami dsar Ilmu Hukum, Prenadamedia, Jakarta , 2018, hlm. 27
} 
Berbeda dengan Utrech yaitu Imanuel Kant, menurutnya, hukum adalah keseluruhan peraturan yang dibatasi oleh hak orang lain. Maka dari itu, setiap orang harus menghargai hak maupun kewajiban orang lain selama tidak merugikan pihakpihak terkait.

Seteleh diketahui hakekat pendidikan dan hakekat hukum, penulis mencoba merumuskan inti sari dari pendidikan hukum yang sesungguhnya, meski demikian, penulis tetap bersandarkan pada pemikir pendidikan yang lain yaitu Freud sebagai pisau analisa dalam menjawab persolan pertama dalam makalah ini. Berdasarkan pemikiran Sigmund Freud secara tegas pendidikan berdasarkan dan bertujuan untuk menekan id atau emosional anak didik sehingga menjadi dewasa. Emosi anak didik menjadi terkontrol dan terkendali. Sehingga kalau dikaitkan dengan kasus advokat yang memukuli hakim, jelas bahwa $I d$ atau pemuasan nafsu dari advokat itu lebih dominan dibandingkan dengan ratio akal atau super egonya. Karena itulah maka sudah sangat tepat jika Indonesia merumuskan tujuan pendidikan bertumpu pada mencerdaskan kehidupan bangsa dan mengembangkan manusia Indonesia seutuhnya, yaitu manusia yang beriman dan bertaqwa terhadap Tuhan Yang Maha Esa dan berbudi pekerti luhur, memiliki pengetahuan dan keterampilan, kesehatan jasmani dan rohani, kepribadian yang mantap dan mandiri serta rasa tanggung jawab kemasyarakatan dan kebangsaan.

Dengan adanya pendidikan, maka akan timbul dalam diri seseorang untuk berlomba-lomba dan memotivasi diri kita untuk lebih baik dalam segala aspek kehidupan. Pendidikan merupakan salah satu syarat untuk lebih memajukan pemerintah. Pada intinya pendidikan itu bertujuan untuk membentuk karakter seseorang yang beriman dan bertakwa kepada Tuhan Yang Maha Esa. Pendidikan yang dimaksud bukan hanya menekankan pada intelektual saja, dengan tolok ukur nilai nilai berujud angka. Namun harus bergeser pada proses pembentukan karakter dan budi pekerti anak. Pendidikan harus menghasilkan anak didik yang berkecerdasan intelektual (IQ) tinggi serta berkecerdasan emosional $(E Q)$ dan berkecerdasan spiritual $(S Q)$ yang tinggi.

Sebab menurut penelitian kecerdasan intelektual $(I Q)$ hanya memberi hanya bekontribusi 20 persen terhadap kesuksesan hidup seseorang. Sisanya, 80 persen bergantung pada kecerdasan emosi, kecerdasan sosial, dan kecerdasan spiritualnya. Kecerdasan emosional mampu melatih kemampuan untuk mengelola perasaannya, kemampuan untuk memotivasi dirinya, kesanggupan untuk tegar dalam menghadapi frustasi, kesanggupan mengendalikan dorongan, dan menunda kepuasan sesaat, mengatur suasana hati yang reaktif, serta mampu berempati dan bekerja sama dengan orang lain. Jadi tujuan-tujuan pendidikan yang dinyatakan berdasarkan analisis psikoanalisis adalah memberi tuntunan bagi pendidik dan anak didik tentang apa yang hendak dicapai, kegiatan-kegiatan yang mereka lakukan, dan tentang kemajuan yang dicapai oleh anak didik.

Bagaimana dengan proses pembelajaran menurut Freud, agar tujuan pendidikan yang mendewasakan itu bisa diwujudkan sebab belajar adalah kegiatan yang berproses dan merupakan unsur yang sangat fundamental dalam 
penyelenggaraan setiap jenis dan jenjang pendidikan. ${ }^{16}$ Artinya berhasil atau gagalnya pencapaian tujuan pendidikan bergantung pada proses belajar yang dialami peserta didik, ketika berada di sekolah maupun lingkungan rumah atau keluarganya sendiri. Pemahaman yang benar mengenai arti belajar dengan segala aspek, bentuk, dan manifestasinya mutlak diperlukan oleh para pendidik khususnya para Dosen. Kekeliruan atau ketidaklengkapan persepsi Dosen terhadap proses belajar dan hal-hal yang berkaitan dengan belajar, mungkin akan mengakibatkan kurang bermutunya hasil pembelajaran yang dicapai peserta didik. Berhubungan dengan kendala-kendala dalam kegiatan belajar anak didik, seorang dosen dapat mengukur dari tiga aspek, yaitu: pertama, perkembangan motor (motor development), yakni proses perkembangan yang progresif dan berhubungan dengan perolehan aneka ragam keterampilan fisik anak (motor skills). Kedua, perkembangan kognitif (cognitive development), yakni perkembangan fungsi intelektual atau proses perkembangan kemampuan/kecerdasan otak. Ketiga, perkembangan sosial dan moral (social and moral development), yakni proses perkembangan mental yang berhubungan dengan perubahan-perubahan cara anak berkomunikasi dengan orang lain, baik sebagai individu maupun sebagai kelompok. Ketiga aspek tersebut harus dipegang teguh oleh seorang pendidik. Karena para dosen sekarang sudah terfasilitasi lembaga pendidikan untuk menekuni berbagai bidang ilmu pengetahuan.

Pendidikan hukum pada hakekatnya adalah proses mendewasakan anak didik yang dilakukan oleh orang dewasa secara intelektual, dewasa secara spiritual, dan dewasa secara etika, kepada peserta didik untuk meraih jenjang kecerdasan intelektual yakni memahami hukum, kecerdasan tingkah laku yakni bersikap santun sopan yang berpedoman pada etika profesi, dan kecerdasan spiritual, yakni mampu menerapkan ajaran religi pada situasi dan sikap sekarang dan terkini.

\section{Formulasi Pendidikan Hukum di Indonesia di Masa Yang Akan Datang}

Bagaimana formulasi kedepan pendidikan hukum di Indonesia? Persoalan kedua ini pernah dijawab oleh pakar hukum Prof. Dr. Bagir Manan dalam makalah yang dimuat di Hukum Online. Menurut Profesor Bagir Manan, pendidikan tinggi hukum di Indonesia belum terintegrasi antara lembaga pendidikan dengan kepolisian, pengadilan maupun kejaksaan dan tentu advokat sebagai penegak hukum di Indonesia. Akibatnya lulusan perguruan tinggi hukum ketika memasuki dunia praktisi tidak bisa mengikuti atau ngeklic langsung. Karena tidak ter integrasi dalam sistem hukum di Indonesia, maka masing-masing intitusi kemudian membuat pelatihan atau workshop untuk meningkatkan pengetahuan praktis dibidangnya masing-masing. Seperti bagi calon hakim sebagai penegak hukum, sebelum masuk ke cakim, harus melalui pendidikan khusus hakim. Demikian juga dengan Polisi, Jaksa dan Advokat, masing-masing punya model pendidikan dan pelatihan menurut versinya masing masing.

${ }^{16}$ Muhibbin Syah.2010. Psikologi Pendidikan dengan Pendekatan Baru, Bandung: PT. Remaja RosdaKarya. hlm. 87 
Dengan struktur dan isi kurikulum yang terkotak-kotak seperti sistim penjurusan atau program studi yang ketat- menyebabkan mahasiswa dan lulusan hanya berpikir dalam kotak-kotak tersebut. Tidak jarang, mahasiswa atau sarjana hukum begitu bangga kalau berada dalam lingkungan program studi tertentu seperti progran studi hukum-internasional atau hukum bisnis dan tidak ada perasaan kurang karena tidak menguasai bidang hukum lain seperti hukum pidana, hukum perdata, hukum administrasi atau hukum tata negara. Meskipun cabang-cabang atau disiplin iimu hukum yang disebut terakhir merupakan hal yang wajib, tetapi tetap menganggap hal tersebut sebagai sesuatu yang kurang penting dibandingkan dengan program studi utamanya. ${ }^{17}$

Formulasi yang saat ini digunakan dalam model pendidikan yang menyebabkan tidak terintrgrasinya pendidikan hukum, yang menyebabkan anak didik tidak dewasa dalam tanda kutip, harus segera ditinggalkan dan sudah seharusnya pendidikan tinggi mengganti dengan formulasi baru yakni menjadikan pendidikan hukum di perguruan tinggi yang terpadu.

Meletakkan dan menyadari dengan sungguh-sungguh pendidikan hukum sebagai subsistim dari sistim hukum sangat penting dan mendasar. Pendekatan ini akan memungkinkan pendidikan hukum tersusun secara terpadu dan fungsional, baik secara teoritis maupun praktis dengan semua komponen sistim hukum (aturan hukum, penyelenggara hukum, profesi hukum, pendidikan hukum, pembentuk hukum, dan pendidikan hukum) ${ }^{18}$.

Kondisi pendidikan hukum saat ini untuk kurikulum pendidikan tinggi hukum yang merumuskan tujuan pendidikan hukum sudah ada pembaharuan kurikulum, yakni dirumuskan tujuan pendidikan yang baru, antara lain menyiapkan sarjana hukum yang siap pakai. Sesuai dengan tujuan tersebut, penyesuaian isi mata kuliah yang sudah ada supaya lebih bermakna siap pakai. Selain itu, diadakan pula berbagai pendidikan keterampilan (legal drafting, contract drafting), dan berbagai pecahan atas mata kuliah yang sudah ada agar lebih spesifik. Tetapi berbagai pembaharuan itu tidak mengurangi keluhan mengenai produk pendidikan hukum. Keluhan lama seperti "tidak siap pakai" tetap saja muncul ke permukaan.

Menurut Bagir dengan pendekatan pragmatik masih timbul keluhan baru antara lain para lulusan tidak mempunyai dasar legal reasoning yang memadai, rendahnya penguasaan teoritik sebagai dasar berpikir rasional dan sistimatik. Akibatnya, tidak diseleksi mengenai siapa yang sesungguhnya memerlukan jenjang struktural tersebut, sehingga lebih banyak tampil sebagai pajangan dari pada subtansinya. Bagir menambahkan masih terjadi penyalahgunaan, baik dari penyelenggara pendidikan maupun para peminat. Dari penyelenggara pendidikan, jenjang struktural ini lebih dilihat sebagai sumber pendapatan baru. Dari para

17 Bagir Manan, Peranan Pendidikan Hukum dalam Pembangunan dan Penegakkan Hukum untuk Masa Depan Indonesia, Makalah disampaikan pada peresmian digital campus Univ. Pelita Harapan, Jumat, 20 Pebruari 2004

${ }^{18}$ Ibid 
peminat, kesempatan ini bukan untuk menghasilkan mutu tetapi sekedar mengumpulkan berbagai gelar baru. Bahkan, pendidikan lanjutan profesi seperti notariat diubah menjadi pendidikan gelar lanjutan. Selain untuk memperluas peminat juga dirasa lebih bermakna dengan situasi pendidikan gelar daripada pendidikan profesi.

Kelemahan tersebut menurut penulis harus segera dirubah dan dirumuskan dengan model pendidikan baru, mengenai tujuan pendidikan tinggi hukum, kurikulum juga harus segera dirubah sesuai dengan kebutuhan saat ini, dalam rangka menuju pada tujuan utama pendidikan yakni mencerdaskan kehidupan bangsa.

Secara praktis penulis setuju dengan ide dari Profesor Bagir Manan yakni memasukan mata kuliah dengan pendekatan lintas sejarah pemikiran yang bersifat tematis. Seperti tema masyarakat dan hukum, yang meliputi sub tema hukum dan kesadaran hukum, hukum dan pembangunan, hukum dalam perspektif perubahan sosial. Tema lain seperti tujuan hukum dan fungsi hukum yang mencakup bahasan hukum sebagai tujuan, hukum sebagai instrumen dan lain-lain. Menurut Bagir, selain lebih kongkrit, pendekatan teoritis ini akan melatih mahasiswa berpikir lintas teori atau pemikiran yang terkotak-kotak untuk menuju cara berpikir yang komprehensif dan integral.

Dalam pendidikan integral ini dapat pula ditunjang dengan mengembangkan sistim hukum sebagai mata kuliah yang berdiri sendiri termasuk kajian mengenai pendidikan hukum. Latihan berpikir komprehensif rasional tidak identik dengan menyajikan sebanyak-banyaknya aneka ragam disiplin ilmu. Sebaran mata kuliah yang terlalu banyak dengan sistim pendidikan dalam semester yang singkat tanpa ditunjang oleh sistim penyajian dan fasilitas yang memadai, menjadi salah satu faktor lemahnya sarjana hukum untuk menjalankan peran yang diharapkan, baik dalam memenuhi tuntutan pembangunan maupun penegakkan hukum. Kelemahan lain dari pendidikan tinggi ilmu hukum adalah pengajaran etika hukum dalam profesi hukum belum menjadi komponen utama pendidikan hukum. Sehingga dalam kurikulum harus masuk etika hukum yang berlandaskan pada etika religius.

\section{Penutup}

\section{Kesimpulan}

1. Hakekat pendidikan hukum adalah mendewasakan anak didik untuk mandiri, obyektif independen, memilki karakter budi pekerti luhur, berkecerdasan intelektual, emosional, sosial dan spiritual yang tinggi.

2. Pendidikan hukum kedepan dirancang untuk mampu menciptakan anak didik yang cerdas sesuai dengan tujuan pendidikan yang termuat dalam kosntitusi, dengan menekankan pada etika religius, serta memasukan kurikulum terintegrsi yang menekankan pada berfikir yang komprehensif praktis dan teoritis.

\section{Saran}

1. Pada penentu kebijakan untuk secara sungguh sungguh merancang kurkulum yang sesuai dengan konstitusi, yang berisikan muatan spiritual dan menhilangkan muatan materialistis. 
2. Universitas penyelenggara pendidikan tinggi hukum harus benar benar bersungguh-sungguh dalam mengelola pendidikan tinggi yang outputnya sesuai dengan kebutuhan pasar serta menciptakan sarjana yang memiliki integritas.

\section{Buku}

\section{DAFTAR PUSTAKA}

Hasan Langgulung, 2003, Pendidikan Islam Dalam Abad 21, Cetakan ketiga, PT. Pustaka Al-Husna Baru, Jakarta.

M. Djumransjah, 2004, Pengantar Filsafat Pendidikan, Cetakan Pertama, Bayu Media Publishing, Malang.

M. Ngalim Purwanto, 2003, Ilmu Pendidikan Teoritis Dan Praktis, Edisi Kedua,

Cetakan Kelima Belas, PT. Remaja Rosdakarya, Bandung.

Muhammad Attiyah Al-Abrasyii, Tanpa Tahun, Ruuhu At-Tarbiyah Wa At-Ta'liim,

Cetakan Kesepuluh, (Al-Qoohirah; Daar Ihkyaau Al-Kutub Al'Arobiyah).

Muhibbin Syah, 2010, Psikologi Pendidikan Dengan Pendekatan Baru,:PT. Remaja Rosdakarya Bandung.

Prasetya, 2000, Fisafat Pendidikan Untuk IAIN, PTAIN, PTAIS, Cetakan ke-dua, CV. Pustaka Setia, Bandung.

Sri Warjiyati, 2018, Memahami dasar Ilmu Hukum, Prenada Media, Jakarta.

Jurnal:

Alif Cahya Setiyadi, Konsep Demokrasi Pendidikan Menurut John Dewey, AtTa'dib Vol. 5. No. 1 Shafar 1430

Undang-Undang dan Peraturan:

Undang-Undang Dasar Negara Republik Indonesai Tahun 1945

Undang-Undang Nomor 20 Tahun 2003 tentang Sistem Pendidikan Nasional (Sisdiknas),

Undang-Undang Nomor 12 Tahun 2012 tentang Pendidikan Tinggi

\section{Kamus}

Kamus Besar Bahasa Indonesia (KBBI)

Internet:

https://www.zonareferensi.com/pengertian-pendidikan/, diakses Senin 29 Juli 2019 pukul 10.30.

Rhara Irawan, Konseling Psikoanalisis, Sejarah Hidup Sigmund Freud, ttps://www.academia. edu/30268490

Halelaluddin Syawal, Psikoanalisis Sigmund Freud dan Implikasinya dalam Pendidikan, www.researchgate.net/publication/323535054

Makalah:

Bagir Manan, Peranan Pendidikan Hukum dalam Pembangunan dan Penegakkan Hukum untuk Masa Depan Indonesia, Makalah disampaikan pada peresmian digital campus Univ. Pelita Harapan, Jumat, 20 Pebruari 2004 